\title{
ARE AQUATIC RESOURCES OF THE MT. ZIRKEL WILDERNESS AREA IN COLORADO AFFECTED BY ACID DEPOSITION AND WHAT WILL EMISSIONS REDUCTIONS AT THE LOCAL POWER PLANTS DO?
}

-By John T. Turk and Donald H. Campbell

U.S. Department of the Interior-U.S. Geological Survey

A combination of changes in the chemistry of rain, snow, and lakes or temporary ponds is expected to contribute to aquatic ecosystem damage in and near the Mt. Zirkel Wilderness Area. The Mt. Zirkel Wilderness Area is a Class 1 area that is given the greatest level of protection under the Clean Air Act. Farther downwind is Rocky Mountain National Park, another Class 1 area that also may be affected by acid rain and snow.

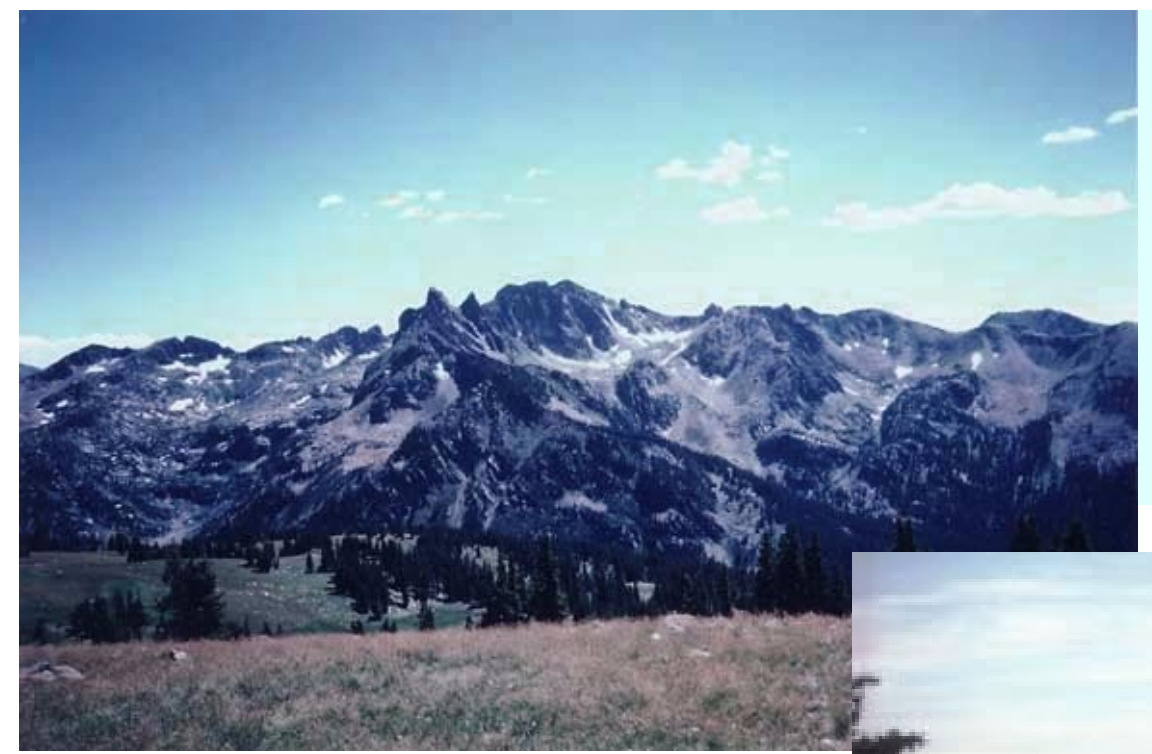

Clean air is critical to maintain spectacular vistas, such as that of Big Agnes Mountain. Clean air also is critical to the health of wilderness streams and lakes, such as Seven Lakes. Both photos are from the Mt. Zirkel Wilderness Area in Colorado, which has the most acidic snow in the Rocky Mountains.

The alpine and subalpine zones of the Rocky Mountains are among the largest undisturbed ecosystems in the United States. The Wilderness and Clean Air Acts give congressionally designated wilderness areas special protection from man-made change. However, many wilderness areas, including the Mt. Zirkel Wilderness Area, of the Rocky Mountains are located near economic deposits of fossil fuels (including some already developed), such as coal, petroleum, natural gas, and oil shale. To use these fossil fuels without damaging nearby wilderness areas and other Federal lands, the present environmental status of the wilderness areas and the possible risk of air pollution from future energyresource development need to be understood.

Little is known about the aquatic ecology of Rocky Mountain wilderness areas because access is limited by lack of roads, steep terrain, and snow accumulation that lasts about 9 months of the year. Most of the scientific information pertaining to these areas is from occasional short-term or "snapshot" samples collected from snow or lakes over a large area, together with some regular sampling and research in a few small watersheds. Lack of information

on the ecology of Rocky Mountain wilderness areas hampers their protection as well as the development of fossil fuels. In the absence of scientific information needed to predict the effects of new emissions sources, Federal land management agencies are required by law to make conservative decisions that ensure no damage is done to the environment. As a result, worst-case estimates of potential risks related to proposed energy-resource development commonly are used.

Knowledge of the present environmental conditions of Rocky Mountain wilderness areas and the risk of damage to them primarily is a result of study of acid deposition and related water-quality issues (Turk and Spahr, 1991). The 


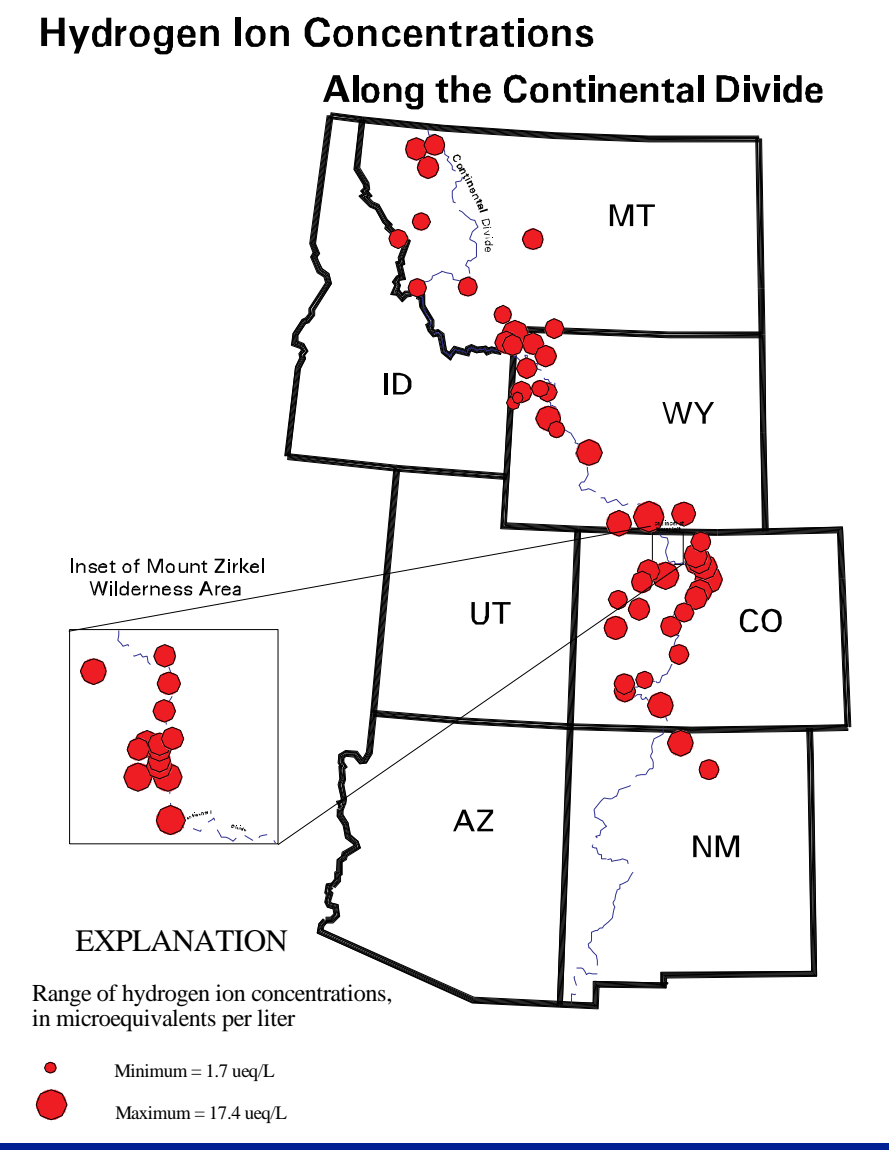

Figure 1. Concentration of hydrogen ion (acidity) in the Rocky Mountain snowpack at end of 1992-93 snow season. A concentration of $10 \mu \mathrm{eq} / \mathrm{L}$ equals a $\mathrm{pH}$ of 5 , and greater concentrations equal $\mathrm{pH}$ less than 5 (more acidic). The greatest concentrations are in and near the Mt. Zirkel Wilderness Area, Colorado.

National Atmospheric Deposition Program monitors the chemistry of rain and snow at about a dozen sites in the Rocky Mountain area. No sites are located in wilderness areas and few are located at elevations higher than about $9,000 \mathrm{ft}$. To better define the extent of acid deposition in the Rocky Mountains, the U.S. Geological Survey (USGS) has conducted annual surveys of snowpack chemistry since 1993. Generally, the lowest concentrations of products resulting from fossil-fuel combustion, such as sulfate, nitrate, and acidity in rain or snow and the snowpack, are in Montana (fig. 1). Concentrations are higher southward in Wyoming and Colorado. Some of the highest concentrations of sulfate, nitrate, and acidity were measured at several sites in northern Colorado downwind (east) of the Yampa River valley. The Yampa River valley is an area of energy development, including coal mining, and generation of electrical energy in coal-fired power plants (fig. 2).

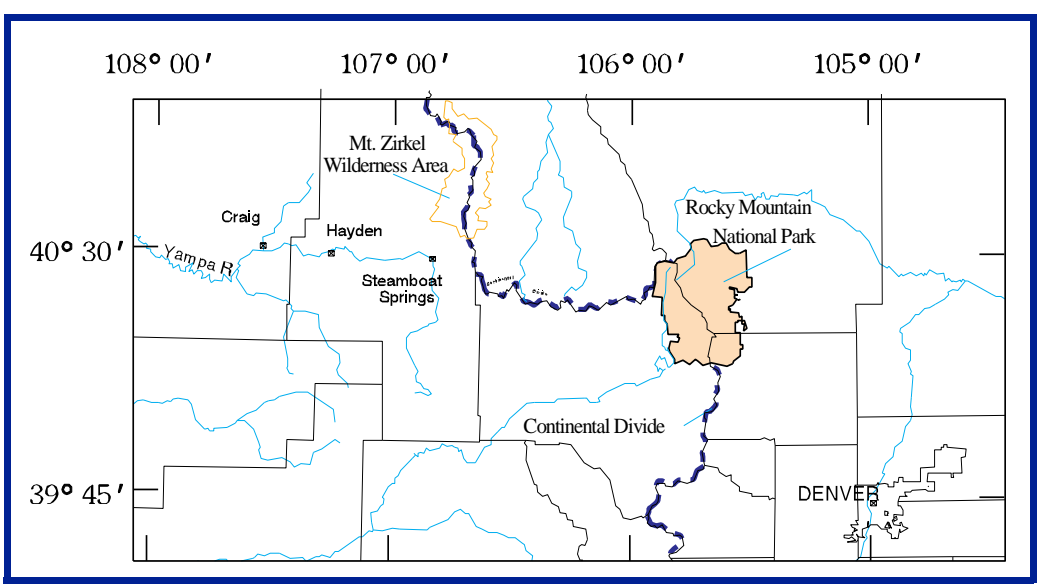

Figure 2. Location of Yampa River valley, Mt. Zirkel Wilderness Area, and Rocky Mountain National Park. Coal-fired power plants are located in Craig and Hayden.

The Western Lake Survey, conducted by the U.S. Environmental Protection Agency in 1985, and numerous smaller surveys indicated that acid neutralizing capacity (ANC) differs greatly among regions in the Rocky Mountains. ANC is a measure of a lake's ability to neutralize acidity, and lakes having small ANC occur throughout the Rocky Mountains. Because of differences in bedrock geology, soil development, and hydrology, those lakes having smallest ANC tend to be in specific mountain ranges such as the Bitterroot Range in Montana, the Wind River Range in Wyoming, the Uinta Mountains in Utah, the Colorado Front Range (including Rocky Mountain National Park), and the northern Park Range in Colorado (including the Mt. Zirkel Wilderness Area).

In northern Colorado, downwind of the Yampa River valley, an area of high concentrations of sulfate, nitrate, and acidity in wetfall and snowpack overlaps an area containing lakes having very small ANC. Thus, at present (1997) levels of emissions from all sources, including energy development, the Mt. Zirkel Wilderness Area contains hydrologic systems that may be the most affected by acid deposition in the Rocky Mountains.

Problems with access have limited the ability to do detailed scientific studies in the Mt. Zirkel Wilderness Area. Although no lakes were acidic during the summer when all sampling has been done, the greatest concentrations of acidity are released during early stages of snowmelt. Such an acid pulse most likely would first affect small, temporary snowmelt ponds favored by amphibians for breeding. Other studies (Harte and Hoffman, 1989; Kiesecker, 1996) indicate that the tiger salamander, which is native to the area, is sensitive to acidity at $\mathrm{pH}$ values commonly observed in the snowpack and wetfall in and near the Mt. Zirkel Wilderness Area. 
The USGS has examined the release of pollutants from the snowpack in an acid pulse at the USGS Water, Energy, and Biogeochemical Budgets (WEBB) site in the Loch Vale watershed in Rocky Mountain National Park. The relative amplification of snowpack acidity in the early stages of snowmelt has been determined at the WEBB site. An amplification factor was applied to the measured acidity in the snowpack at Buffalo Pass, adjacent to the Mt. Zirkel Wilderness Area. Projections indicate that the early snowmelt that fills temporary ponds used by amphibians for breeding likely is more acidic than the level at which biological damage occurs (fig. 3). In the area around Dumont Lake, just south of the Mt. Zirkel Wilderness Area, 60 to 100 percent of tiger salamander eggs were dead or unviable in ponds at about $\mathrm{pH} 5.0$ or less, about 40 percent between $\mathrm{pH} 5.0$ and 6.0, and about 20 percent were dead or unviable at about $\mathrm{pH} 6.0$ or greater (Kiesecker, 1991). Laboratory experiments using these eggs indicated that $\mathrm{pH}$ lower than about 6.0 also resulted in slower hatching of eggs, slower growth to maturity, and decreased ability to catch and eat tadpoles, which are a common food. At less than about $\mathrm{pH}$ 6.0, growth to maturity was so slow that ponds would be likely to dry up, and salamanders would die before they could mature. Smaller size also made them more susceptible to predation. Harte and Hoffman (1989) reported that less than half as many tiger salamander embryos survived at about $\mathrm{pH} 5.6$ or less compared to those surviving at about $\mathrm{pH} 6.1$ or greater. Salamanders that survive toxic conditions, drying up of ponds, and predation as eggs or larvae may have to survive a second acid pulse the following year. Some individual salamanders may be genetically able to mature in two years rather than maturing in their first year. However, they would have to winter over in deeper ponds and would still be in the acid-sensitive larval stage during snowmelt of the following spring.

Although the tiger salamander seems to be the only aquatic species studied in natural habitats adjacent to the Mt. Zirkel Wilderness Area, other species in the wilderness are also sensitive to acid toxicity. Embryos of other amphibians, such as boreal toads, chorus frogs, northern leopard frogs, and wood frogs have as much as 50 percent mortality at $\mathrm{pH} 4.3$ to 4.8 (Corn and Vertucci, 1992). Embryo and fry of rainbow trout have increased mortality at about pH 5.5 (Baker and Christensen, 1991). Three zooplankton species that are common food for the tiger salamander and for fish had 100 percent mortality within 1-5 days of exposure to a pH of 5.0 (Harte and Hoffman, 1989). Thus, in sensitive ponds, streams, and lakes in and near the Mt. Zirkel Wilderness Area, a wide range of biological damage may occur.

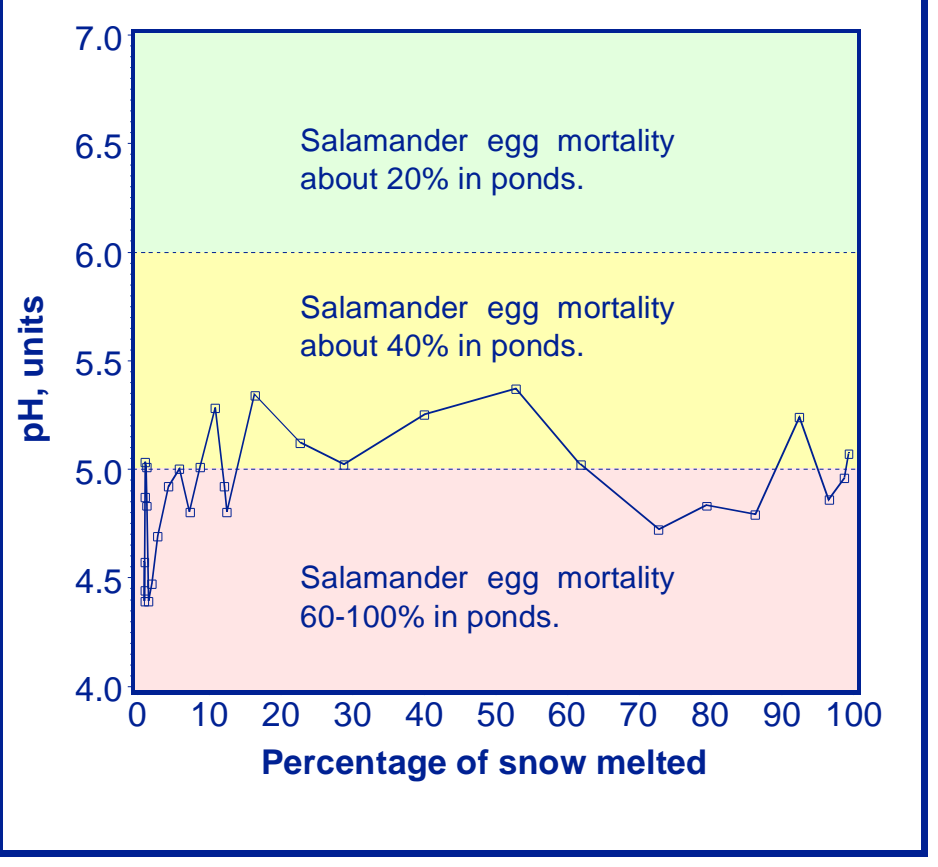

Figure 3. Predicted acidity, expressed as $\mathrm{pH}$, of snowmelt at Buffalo Pass, adjacent to the Mt. Zirkel Wilderness Area, in 1995. Calculated as the product of bulk snowpack acidity at Buffalo Pass and amplification factors in acid pulse of snowmelt at Loch Vale, Rocky Mountain National Park, Colorado. [Mortality data from Kiesecker (1991).]

Between December 1992 and May 1993, the Hayden Power Plant was partially shutdown because of mechanical problems, which resulted in a 58-percent decrease in its sulfur dioxide emissions (Dan Ely, Colorado Department of Public Health and Environment, written commun., 1997). The USGS sampled snow deposited in and near the Mt. Zirkel Wilderness Area during normal operation and during the period of partial shutdown. Although the Hayden Power Plant is the largest local source of sulfur dioxide (Watson and others, 1996) and although sulfur dioxide emissions were reduced during shutdown, acidity of the snowpack increased during the partial shutdown and remained at levels determined to be injurious to amphibians. The most likely explanations of the still-toxic snowpack acidities are a combination of: (1) Seasonal differences in snow chemistry, and (2) a likely overload of the ability of the local atmosphere to fully convert all the sulfur dioxide to sulfuric acid. At present (1997) emissions rates of sulfur dioxide from all local sources, the natural production rate of oxidants in the atmosphere may control the amount of sulfuric acid produced and deposited to the snowpack.

It is not known how much emissions reduction may be required from all local sources before sulfuric acid produc- 
tion and deposition become controlled by emissions rates and would be reduced. Pollution controls that are planned for the Hayden Power Plant are expected to reduce sulfur dioxide emissions from the plant by about 85 percent (Dan Ely, Colorado Department of Public Health and Environment, oral commun., 1997). However, no studies have been done to indicate the effectiveness of this level of emissions reduction. Data collected during the partial shutdown of the Hayden Power Plant indicated that a reduction of 58 percent had no measurable effect. Therefore, it is possible that the pollution controls will not fully remedy problems related to the acidity of the snowpack.

Because the Mt. Zirkel Wilderness Area may be the area most affected by acid deposition in the Rocky Mountains and because reductions in local emissions of acid precursors are planned, an opportunity exists to investigate the causes and effects of acid deposition that could help protect all Rocky Mountain wilderness areas. Little scientific information exists to indicate which aspects of the hydrologic and biologic systems of Rocky Mountain watersheds are most sensitive to acidification. Further, although some damage to aquatic resources likely occurs at present levels of emissions, natural hydrologic and other processes might protect these ecosystems in ways not documented elsewhere. Documentation of the effects of acidification on lakes and aquatic organisms could provide a benchmark for evaluating effects of energy development and associated emissions everywhere in the Rocky Mountains.

\section{REFERENCES}

Baker, J.P., and Christensen, S.W., 1991, Effects of acidification on biological communities in aquatic ecosystems, in Charles, Don F., ed., Acidic deposition and aquatic ecosystems-Regional case studies: New York, Springer-Verlag, $747 \mathrm{p}$.

Corn, P.S., and Vertucci, F.A., 1992, Descriptive risk assessment of the effects of acidic deposition on Rocky Mountain amphibians: Journal of Herpetology, v. 26, p. 361-369.

Harte, John, and Hoffman, Erika, 1989, Possible effects of acidic deposition on a Rocky Mountain population of the tiger salamander Ambystoma Tigrinum: Conservation Biology, v. 3, p. 149-158.

Kiesecker, Joseph, 1991, Acidification and its effects on amphibians breeding in temporary ponds in montane Colorado: Greeley, University of Northern Colorado, Master's thesis, $78 \mathrm{p}$.

Kiesecker, Joseph, 1996, pH-mediated predator-prey interactions between Ambystoma Tigrinum and Pseudacris Triseriata: Ecological Applications, v. 6, p. 1325-1331.

Turk, J.T., and Spahr, N.E., 1991, Rocky Mountains, in Charles, Don F., ed., Acidic deposition and aquatic ecosystems-Regional case studies: New York, Springer-Verlag, $747 \mathrm{p}$.

Watson, J.G., Blumenthal, D., Chow, J., Cahill, C., Richards, L.W., Dietrich, D., Morris, R., Houck, J., Dickson, R.J., and Andersen, S., 1996, Mt. Zirkel Wilderness Area reasonable attribution study of visibility impairment, Volume II: Reno, Desert Research Institute.
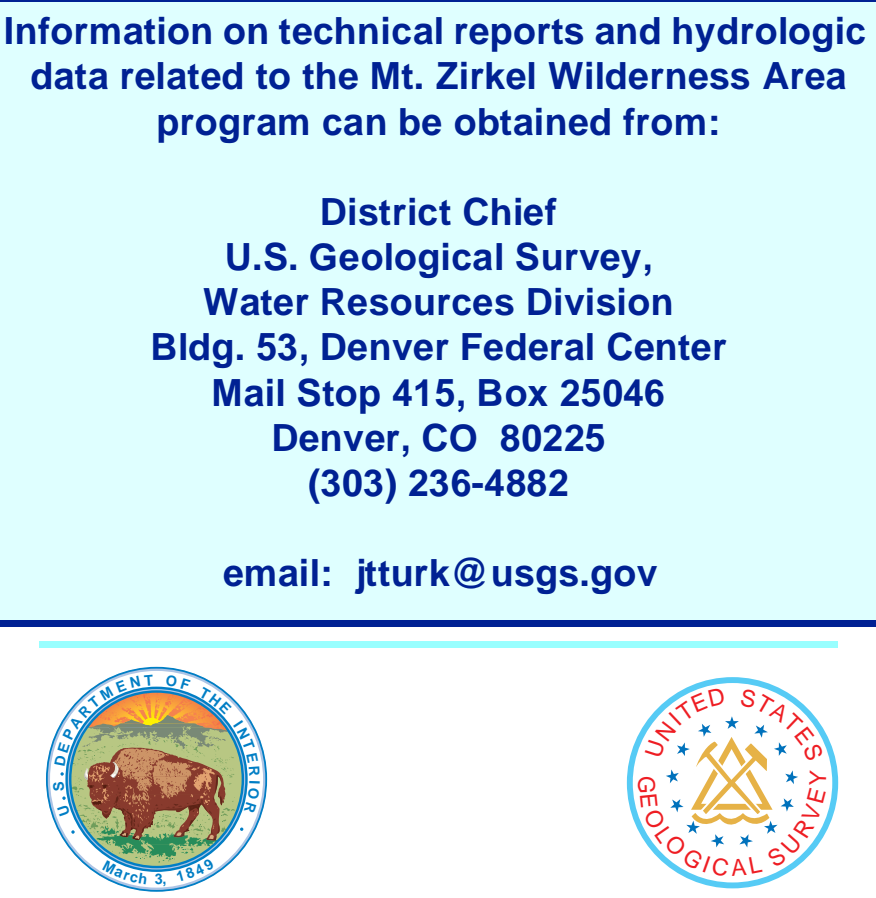